\title{
Durability of particleboards made from wood particles chemically modified with propionic anhydride: Results after six years in ground stake-test
}

\begin{abstract}
Antonios N. Papadopoulos
Technological Educational Institute of Kavala, Branch of Drama, Department of Forestry and Management of Natural Environment, Laboratory of Wood Science and Technology, TK 66100, Drama, Greece. E-mail antonios1974@hotmail.com
\end{abstract}

\begin{abstract}
Propionylated particleboard stakes with $12.2 \%$ propionyl content were tested in ground contact in Western Greece. The stakes showed severe attack after five years of testing and total decay after six years, whereas the unmodified boards showed total decay during the fourth year of testing.
\end{abstract}

\section{Introduction}

Chemical modification has been used to improve decay resistance of wood. The majority of research investigating this area was concerned with the reaction of acetic anhydride with wood. It was shown that acetylation imparts excellent protection against decay, provided that a certain degree of acetylation is reached (Rowell 1975, Hill 2006). This paper examines the decay resistance in ground stake test of particleboards made from wood chips modified with propionic anhydride and is an update of an earlier paper (Papadopoulos 2007). 


\section{Experimental}

The propionylation of wood chips (weight gain of $12.2 \%$ after 60 minutes at $120^{\circ} \mathrm{C}$ ) and the laboratory manufacture of boards are fully described in a previous paper (Papadopoulos and Gkaraveli 2003). The ground stake test was carried out as described earlier (Papadopoulos 2007).

\section{Results and discussion}

The performance of propionylated stakes during the testing period is shown in Table 1. It was reported earlier (Papadopoulos 2007) that after three years of exposure in ground stake test the propionylated stakes were moderately attacked, whereas the control stakes were severely attacked (grey part in Table 1). The upper part of Table 1 shows the performance of the stakes during the following three years. It can be seen that the control stakes were totally decayed during the fourth year of the test. The propionylated stakes showed severe attack after five years of testing and total decay after six years.

\section{References}

Hill CAS (2006) Wood modification - chemical, thermal and other processes. John Wiley and Sons Ltd., West Sussex

Rowell RM (1975) Chemical modification of wood: Advantages and disadvantages. Proceedings American Wood Association 71, 41-51

Papadopoulos AN (2007). Natural durability in ground stake test of propionylated particleboards. Holz Roh- Werkst 65(2):171-172 
Papadopoulos AN, Gkaraveli A (2003). Dimensional stabilization and strength of particleboard by chemical modification with propionic anhydride. Holz Roh- Werkst 61(2):142-144

Table 1. Decay rating of control and propionylated boards in ground stake test (a rating of 10 means no decay, 9 slight decay, 7 moderate decay, 4 severe decay and 0 means total decay)

Tabelle $1 \quad$ Befallsgrad der Kontrollproben und propionylierten Proben im Erdkontakt $(10=$ kein Befall, $9=$ leichter Befall, $7=$ mäßiger Befall, $4=$ starker Befall, 0 = vollständig zerstört)

\section{Decay rating}

$\begin{array}{lcc}\text { Exposure time } & \text { Control } & \text { Propionylated (12.2\%) } \\ 72 \text { months } & 0 & 0 \\ 60 \text { months } & 0 & 4 \\ 48 \text { months } & 0 & 4 \\ 36^{1} \text { months } & 4 & 7 \\ 24^{1} \text { months } & 7 & 10 \\ 12^{1} \text { months } & 10 & 10\end{array}$

1. Data from Papadopoulos (2007) 